\title{
Konsistensi Nahdlatul Ulama' dalam Mempertahankan Pancasila dan Kedaulatan Negara Kesatuan Republik Indonesia di tengah Wacana Negara Islam
}

\author{
Amin Farih ${ }^{1}$ \\ Universitas Islam Negeri Walisongo, Semarang - Indonesia
}

\begin{abstract}
Since its establishment, NU has always prioritized the interests of the nation and state based on Islamic shari'a and Islamic values, Indonesianism and has a high spirit of nationalism. By using qualitative research and historical methods, this article comprehensively describes how NU, as one of the largest CSOs in Indonesia has its own way of placing roles and realizing its contribution in upholding the concept of Pancasila and maintaining the sovereignty of Indonesia in the frame of the Unitary State. Republic of Indonesia (NKRI). The results of this study explain that NU refused to firmly reject the idea of khilafah and the concept of an Islamic State in Indonesia, this attitude has been shown by NU by rejecting the presence of the Indonesian Islamic State (NII) founded by Kartosuwiryo. This attitude of rejection of the concept of khilafah was also indicated by the attitude of NU's (Nahdlatul Ulama') recognition that decided the position of the Head of State of the Republic of Indonesia (Ir. Sukarno) as wāliy al-amri al-darūri bi al-shawkah or de facto with full power in the NU Ulema Alim National Conference in Cipanas in 1954 and the 20th NU Congress Decision in Surabaya, 8-13 September 1954. The consistency of the attitude pointed out by NU continued in the New Order and until the reform era, now to keep rejecting the khilafah system.
\end{abstract}

Sejak berdirinya, NU selalu mengutamakan kepentingan bangsa dan negara yang didasarkan atas syariat Islam dan nilai-nilai ke-Islam-an, ke-Indonesia-an serta semangat nasionalisme yang tinggi. Dengan menggunakan penelitian kualitatif dan methode sejarah, artikel ini. begitu komprehensif memaparkan bagaimana NU, sebagai salah satu Ormas (organisasi kemasyarakatan) terbesar di Indonesia memiliki cara tersendiri untuk menempatkan peran dan merealisasikan kontribusinya dalam memegang teguh konsep Pancasila dan mempertahankan kedaulatan negara Indonesia dalam bingkai Negara Kesatuan Republik Indonesia (NKRI). Adapun hasil penelitian ini menjelaskan bahwa NU menolak dengan tegas menolak gagasan khilafah dan konsep Negara Islam di Indonesia, sikap ini sudah ditunjukan NU dengan menolak kehadiran Negara Islam Indonesia (NII) yang didirikan oleh Kartosuwiryo. Sikap penolakan konsep khilafah ini juga ditunjukkan dengan adanya sikap pengakuan NU yang memutuskan bahwa kedudukan Kepala Negara Republik Indonesia (Ir. Soekarno) sebagai wāliy al-amri al-ḍarūri bi al-shawkah atau pemegang pemerintahan sementara (de facto) dengan kekuasaan penuh dalam Konferensi Nasional Alim Ulama NU di Cipanas tahun 1954 dan Keputusan Muktamar NU ke-20 di Surabaya, 8-13 September 1954. Konsistensi sikap yang ditunjukkkan oleh NU berlanjut pada Orde Baru dan sampai era reformasi, sekarang ini untuk tetap menolak sistem khilafah.

Keywords: khilafah; Pancasila; Nahdlatul Ulama'; Negara Islam; NKRI

${ }^{1}$ Korespondensi: Amin Farih (amin.farih@walisongo.ac.id), Kampus 3 UIN Walisongo, Jl. Prof Hamka Km 3 Ngaliyan Semarang 50185. 


\section{Pendahuluan}

Nahdlatul Ulama' (NU) pimpinan KH. Hasyim Asy'ari sangat menjunjung tinggi nilai-nilai kebangsaan dan nasionalisme yang berdasarkan atas sharīat Islam alā Ahlu al-Sunnah wal alJamā'ah (Anam 2010, 36; Siddiq 1985, 18--21). Peranan NU pada ranah kesejarahan, dapat dilihat pada keputusan Muktamar NU ke-2 di Banjarmasin pada tahun 1936. Muktamar memutuskan bahwa kedudukan Hindia Belanda (Indonesia) sebagai Dār al-Islām, yang menegaskan keterikatan NU dengan nusa-bangsa. Proses integrasi ini terjadi melalui beberapa tahap: Pertama, pengakuan wilayah Nusantara sebagai wilayah Islam (Dār al-Islām), yang para ulama NU menetapkan Nusantara sebagai Dār al-Islām. Menariknya, Dār al-Islām ini tidak dimaknai sebagai "negara Islam", melainkan "wilayah Islam", sebab di dalamnya umat Islam bebas melaksanakan sharīat Islam (Anam 2010, 21). Dengan cara ini, NU telah membentuk "kebangsaan Islam" (Islamic nationalism) sebab Dār al-Islām tersebut dipahami sebagai bangsa. Artinya, ketika Nusantara diakui sebagai $D \bar{a} r$ alIslām, wilayah ini telah dipahami sebagai bangsa muslim Indonesia. Kedua, penerimaan atas negara-bangsa (NKRI), bukan negara Islam pada pembentukan konstitusi 1945. Wakil dari NU di sidang PPKI (Panitia Persiapan Kemerdekaan Indonesia), yakni KH. Wahid Hasyim, KH. Masykur, dan KH. Zainul Arifin, telah menyepakati bangunan Negara Kesatuan Republik Indonesia (NKRI) dalam kerangka perawatan kemajemukan bangsa (Feillard 2008, 197). Pada titik ini, NU telah menepis ego kelompok, demi terjaganya masyarakat bangsa yang majemuk.

Ketiga, penetapan pemerintah RI (Republik Indonesia) sebagai pemimpin darurat yang memiliki wewenang menerapkan sharīat (waliy al-amri al-ḍrūri bi al-shaukah). Kesepakatan ulama pada Munas Alim Ulama tahun 1954 ini, ditetapkan agar sharīat Islam bisa ditegakkan, karena pemerintahan sah secara shar'îy. Dari sini terlihat bahwa politik kebangsaan NU tidak bersifat sekuler, karena ia bermuara pada shari’at Islam, baik melalui penerapan partikel hukumnya di dalam hukum nasional, maupun pengamalan sebagai etika sosial. Keempat, penerimaan Pancasila sebagai dasar negara, hal ini ditetapkan pada Munas Alim Ulama NU di Situbondo tahun 1983, Pancasila diterima sebagai dasar negara sedangkan Islam tetap dijaga sebagai aqïdah. Antara aqīdah beragama dan dasar bernegara tidak dibenturkan, sebab Pancasila yang memuat sila ketuhanan, merupakan bentuk pengamalan sharīat Islam (Bruinessen 1994, 76).

Melalui proses integrasi Islam ke dalam nasionalisme ini, $\mathrm{NU}$ telah melerai ketegangan antara Islam sebagai "ideologi universal" dan Pancasila sebagai "ideologi nasional", serta antara Islam sebagai "paham theokratis" dan NKRI sebagai "bangunan negara-bangsa". Sebuah pola hubungan yang hingga saat ini masih menyediakan ketegangan bagi sebagian besar negara Islam di Timur Tengah, karena mereka belum mencapai hubungan harmonis antara Islam dan kemodernan. Dalam kaitan ini, penerimaan NU atas NKRI (Negara Kesatuan Republik Indonesia) digerakkan melalui demokratisasi dalam jangka panjang. Hal ini terjadi karena NU memahami nasionalisme tidak dalam kerangka identitas dan wilayah, melainkan kerakyatan. Hal ini terkait dengan pandangan terhadap kekuasaan yang terkait langsung dengan kemaslahatan rakyat (tașarruf al-imām 'ala al-ra'ìyah manūțun bi al-mașlahah). Melalui pandangan ini, demokrasi yang diperjuangkan bukan demokrasi prosedural, melainkan demokratisasi, baik dalam rangka pemenuhan hak sipil-politik maupun hak sosial-ekonomi.

Dalam kacamata kelompok besar Islam di Indonesia, NU, Pancasila dan Undang-Undang Dasar 1945 adalah harga mati. Dua perangkat landasan terbentuknya Negara Kesatuan Republik Indonesia (NKRI) itu dipandang sebagai 
aktualisasi nilai-nilai ajaran Islam yang dirumuskan para pendiri bangsa dengan mempertimbangkan akidah, hukum, dan akhlak Islam (Wahid 1991, 41, 65). Pada Musyawarah Nasional NU tahun 1983 di Situbondo, Jawa Timur, para pimpinan kelompok Islam terbesar di Indonesia itu melahirkan konsep "kembali ke Khittah 1926". Konsep itu sejatinya menegaskan bahwa NU ingin lepas dari politik praktis yang dalam kepemimpinan Idham Chalid dianggap terlalu dekat dengan penguasa. Namun, ketika itu rezim Orde Baru yang dikomandoi presiden Soeharto rajin menginfiltrasikan Pancasila sebagai asas tunggal bagi seluruh kelompok masyarakat, sosial, maupun partai politik, meski pun saat itu Pancasila sarat dengan tafsir tunggal rezim.

Bagi NU, penerimaan ini bukan tanpa sebab. Apalagi, jika berkaca pada sejarah, salah satu perumus Pancasila sebagai asas negara Indonesia adalah $\mathrm{KH}$ Wahid Hasyim (Mazrui et al. 2006), Ketua Umum PBNU pada masa perjuangan bangsa lepas dari penjajahan, bahkan, pada saat itu KH. Wahid Hasyim berperan besar menengahi dua pemikiran besar yaitu kelompok nasionalis dan kelompok agama Islam yang memperseterukan tujuh kata dalam Piagam Jakarta. Piagam Jakarta adalah cikal bakal materi pembukaan UUD 1945 oleh karena materi Piagam Jakarta kemudian dijadikan materi pembukaan (preambule) UUD 1945. Piagam Jakarta berisi pula kalimat proklamasi kemerdekaan Indonesia yang dinyatakan pada 17 Agustus 1945. Persiapan yang dilakukan oleh para tokoh bangsa termasuk salah satu perumus Pancasila yaitu KH. Wahid Hasyim dari kalangan tokoh agama, beliau melakukan langkah dengan menggelar rapat di Taman Raden Saleh Jakarta pada tanggal 13-14 September 1944. Sebulan kemudian, Masyumi mengadakan rapat khusus dengan kesepakatan untuk mengajukan resolusi kepada Jepang agar segera mempersiapkan umat Islam Indonesia untuk siap menerima kemerdekaan.
Menurut KH. Wahid Hasyim, toleransi yang dilakukan oleh NU (Bizawie 2014, 21) dan tokohtokoh pejuang Muslim lain yang menerima untuk menghapus "tujuh kata" dan menerima tuntutan kaum Kristen Indonesia Timur, itu semua merupakan pengorbanan dan perjuangan para ulama NU demi persatuan dan kesatuan di bawah Negara Kesatuan Republik Indonesia (NKRI). Kita perlu mengingat kembali, bahwa setelah "Piagam Jakarta" ditetapkan, masih ada sebagian anggota Badan Penyelidik Usaha-Usaha Persiapan Kemerdekaan Indonesia (BPUPKI) yang menggugatnya. Akhirnya, Bung Karno sendiri menegaskan: "Saya ulangi lagi bahwa ini satu kompromis untuk menyudahi kesulitan antara kita bersama. Kompromis itu pun terdapat sesudah keringat kita menetes. Tuan-tuan, saya kira sudah jelas bahwa kalimat "dengan didasarkan kepada ke-Tuhanan dengan kewajiban menjalankan syariat Islam bagi pemelukpemeluknya...." sudah diterima oleh Panitia ini" (Hatta 1969, 19; Noer 1994, 308). Inilah debat panjang yang akhirnya menelorkan sikap kompromis yang sebaik-baiknya antara kaum Muslimin dan Kristen. Sehingga panitia memegang teguh akan kompromis yang dinamakan oleh anggota yang terhormat Muh. Yamin dengan nama "Djakarta Charter", yang disertai perkataan Tuan anggota Soekiman, gentlemen agreement, hal ini supaya dipegang teguh di antara pihak Islam dan pihak kebangsaan (Kusuma 2004, 85).

Berkenaan dengan itu perlu disadari, bahwa penerimaan Pancasila sebagai falsafah kehidupan berbangsa dan bernegara telah sesuai dengan spirit "Piagam Madinah" yang digagas oleh Rasulullah yang berhasil menyatukan masyara kat yang plural dalam satu kesatuan negeri Madinah. Dari Piagam Madinah dapat diambil spirit, bahwa Nabi Muhammad menyatukan warga yang multi etnis dan multi agama menjadi ummatan wāhidatan (satu kesatuan bangsa). Semua warga punya kedudukan yang sederajat, 
sama-sama berhak mendapatkan jaminan keamanan, melakukan aktifitas ekonomi, mengaktualisasikan agama, sama-sama berkewajiban untuk saling memberi nasehat dan berbuat kebaikan, menjaga keamanan serta integritas Madinah sebagai satu kesatuan negeri menghadapi ancaman dari luar. Apa yang disampaikan adalah sebagian dari hasil Keputusan Bahtsul Masail Maudhu'izah PWNU Jawa Timur Tentang "Islam Nusantara" di Universitas Negeri Malang pada tanggal 13 Februari 2016. Selain itu, keputusan Bahtsul Masail juga beisi tentang anjuran untuk menjaga kedaulatan bangsa dalam bingkai NKRI (Negara Republik Indonesia) dan menganjurkan untuk memupuk persatuan di tengah masyarakat yang plural sehingga perlu ditanamkan sikap menghargai perbedaan dan menjaga hak antar sesama serta memprioritaskan penanaman nilai-nilai agama secara utuh dan mendalam di lingkungan internal Ahlu alsunnah wa al-Jamä’ah.

Di samping penerimaan Pancasila sebagai asas pemersatu idiologi negara-bangsa, $\mathrm{NU}$ juga mempunyai prinsip tentang kedaulatan bangsa dan keutuhan NKRI. Prinsip utama kedaulatan bangsa-negara bagi umat Islam yaitu menjaga keutuhan negara Indonesia dari berbagai ancaman baik ancaman dalam negeri atau luar negeri, hal ini sangat penting karena Indonesia tengah menghadapi persoalan serius yaitu kemungkinan terjadinya disintegrasi nasional, di mana muncul adanya keinginan mengganti falsafah Pancasila, membentuk Negara Islam, menghembuskan fitnah untuk menghancurkan keutuhan negara Republik Indonesia dan mengancam kesatuan bangsa dari NKRI. Oleh karenanya, menurut NU konsistensi menjaga persatuan untuk memperkokoh integritas bangsa, keutuhan NKRI dan Pancasila adalah hal yang mendasar bagi rakyat Indonesia secara umum dan bagi warga Nahdiyyin secara husus. NU juga telah terbukti mampu menjadi perekat bangsa sejak kemerdekaan hingga sekarang, dan mampu menjadi wadah dakwah Islam Nusantara secara luas (Marijan 1992, 47; Mukhdlor 1996, 21). Namun demikian, di tengah perjalanan sejarah tantangan disintegrasi bangsa terkadang bermunculan, bahkan wacana mendirikan negara di dalam negara terus mengemuka. Berkenaan dengan problematika di atas, maka penelitian ini bermaksud "menguak" atau membedah tawaran NU tentang konsep relasi Agama dan Negara yang dipadukan dengan asas Pancasila dalam bingkai NKRI sebagai wadah negara yang bisa memuat dan mewadahi berbagai etnis pluralitas bangsa yang ada di dalamnya tanpa harus mengusik atau bertentangan dengan kepentingan agama dan bangsa, oleh karenanya persoalanpersoalan terkait dengan relasi agama dan negara dalam konsep Islam ini, merupakan persoalan yang sangat pelik dan kompleks yang perlu kita urai dalam penelitian ini. Walaupun sebenarnya kalau dikaji secara mendalam bahwa teks al-Qur'an tidak pernah mengurai secara detail mengenai relasi tersebut. Dengan demikian perlunya reinterpretasi teks untuk mengkaji hal itu, apakah perlu didirikannya negara Islam khilafah? Apakah negara yang menerapkan nilai universal Islam bisa disebut negara Islam? Atau apakah yang menerapkan sharīah secara käffah maka itu disebut negara Islam? Bagaimana pola hubungan agama dan negara yang bisa mengakomodir seluruh warganya sebagai jaminan kebebasan yang demokratis?

Sederet pertanyaan di atas merupakan kegelisahan yang menjadi problem ormas $\mathrm{NU}$ dalam menyikapi hal tersebut. Dalam perspektif sejarah Islam, pola hubungan antara negara agama juga mengalami determinasi yang serius karena relasi Islam dan negara sangat menimbulkan fenomena keagamaan yang pada titik tertentu menimbulkan pemaksaan pemahaman. Sedangkan dalam teks ajaran Islam, al-Qur'an merupakan teks yang mulititafsir yang dengan 
mudah membuka peluang pluralitas tafsir (sesuai dengan kebutuhan suatu masyarakat). Dengan demikian tidak akan pernah ada kebenaran tafsir yang tunggal untuk memahami relasi antara agama dan negara. Dengan adanya keputusan Muktamar Banjarmasin tahun 1936 itu, maka NU dapat menerima kenyataan tentang kedudukan negara dalam pandangan Islam, wilayah Indonesia adalah sebagai Dār al-Salām (Negara kedamaian) yang memutuskan bahwa NU terkait dengan konsep nusa-bangsa NKRI yang tidak perlu membuat bentuk Negara Islam (NI) (Ramage 2002, 19; Wahid 2001, 87).

Ini disebabkan oleh heteroginitas yang sangat tinggi di antara para warga negara, di samping kenyataan ajaran Islam menjadi tanggung jawab masyarakat tidak tanggung jawab negara. Oleh karenanya menurut NU bahwa gagasan membentuk NI (Negara Islam) di negara kita menjadi Negara Islam Indonesia (NII), sebagai sebuah utopia yang terdengar sangat indah, namun sangat meragukan dalam kenyataan, hal ini belum lagi kalau pihak non-muslim ataupun pihak kaum Muslimin nominal (kaum abangan), tidak berkeberatan atas gagasan mewujudkan negara Islam itu. Jadi gagasan yang semula tampak indah itu, pada akhirnya akan dinafikan sendiri oleh bermacam-macam sikap para warga negara, yang hanya sepakat dalam mendirikan negara bukan agama. Inilah yang harus dipikirkan sebagai kenyataan sejarah. Kalaupun toh dipaksakan untuk mewujudkan gagasan Negara Islam (NI) itu di negara kita, maka yang akan terjadi hanyalah serangkaian pemberontakan bersenjata seperti yang terjadi di negara kita tahun-tahun 50-an.

Tujuan penelitian ini adalah untuk mengkaji dan menganalisis bagaimana peran NU dalam memegang teguh konsep Pancasila dan mempertahankan kedaulatan negara Indonesia dalam bingkai Negara Kesatuan Republik Indonesia (NKRI) di tengah maraknya tawaran konsep khilafah Negara Islam (NI).
Metode penelitian yang digunakan dalam penelitian ini menggunakan metode sejarah, sebagai cara atau prosedur yang sistematis dalam merekonstruksi masa lampau (Abdullah dan Surjomihardjo 1984: 15-20). Pendekatan sejarah ini paling tidak terdapat empat langkah metode sejarah yang peneliti sajikan yaitu: 1) Metode Heuristik. Heuristik adalah kegiatan mencari dan menemukan sumber yang diperlukan. Berhasil-tidaknya pencarian sumber, pada dasarnya tergantung dari wawasan peneliti mengenai sumber yang diperlukan dan keterampilan teknis penelusuran sumber. Berdasarkan bentuk penyajiannya, sumber-sumber sejarah terdiri atas arsip, dokumen, buku, majalah/jurnal, surat kabar, dan lain-lain. Berdasarkan sifatnya, sumber sejarah terdiri atas sumber primer dan sumber sekunder. Sumber primer adalah sumber yang waktu pembuatannya tidak jauh dari waktu peristiwa terjadi. Sumber sekunder adalah sumber yang waktu pembuatannya jauh dari waktu terjadinya peristiwa. Langkah yang penulis lakukan sebagai peneliti sejarah akan menggunakan sumbersumber sejarah terdiri atas arsip, dokumen, buku, majalah/jurnal, surat kabar yang ada kaitannya dengan peran politik NU dalam mempertahankan Pancasila dan kedaulatan Negara Kesatuan Republik Indonesia (NKRI) ditengah maraknya wacana khilafah Negara Islam (NI). 2) Metode Kritik (Kasid 2015, 11; Notosusanto 1978, 36). Langkah kedua yang penulis lakukan adalah pengerjaan studi sejarah yang akademis atau kritis terhadap fakta-fakta yang telah teruji. Oleh karena itu, data-data yang penulis peroleh melalui tahapan heuristik terlebih dahulu penulis lakukan kritik atau disaring sehingga diperoleh fakta-fakta yang seobjektif mungkin. Kritik tersebut berupa kritik tentang otentitasnya maupun kritik tentang kredibilitas isinya (kritik intern). Metode ini dimaksudkan agar memperoleh fakta yang dapat mengantarkan kepada kebenaran ilmiah. 3) Metode Interpretasi, yakni penafsiran fakta untuk ditulis hingga ada artinya, ada maknanya, fakta-fakta tersebut dilihat 
hubungannya, keterkaitannya, disesuaikan dengan fokus, hal terkait, dan kegunaannya hingga betul-betul layak dijadikan bahan dasar penelitian sejarah. 4) Metode Historiografi. tahap terakhir dari kegiatan penelitian ini penulis melakukan rekaman tentang segala sesuatu yang dicatat sebagai bahan pelajaran tentang perilaku yang baik. Sesudah menentukan judul, mengumpulkan bahan-bahan atau sumber serta melakukan kritik dan seleksi, maka mulailah penulis menulis kisah sejarah tentang peran politik NU dalam mempertahankan Pancasila dan kedaulatan Negara Kesatuan Republik Indonesia (NKRI) ditengah maraknya wacana khilafah Negara Islam (NI).

Untuk memperoleh suatu kesimpulan yang akurat, maka peneliti menambah dengan metode analisis data induksi analitik dan analisis komparatif. Induksi analitik; yaitu suatu pendekatan untuk mengumpulkan dan menganalisis data guna mengembangkan dan menguji teori yang terkait dengan kajian ini (Neuman 1994) . Untuk ini maka peneliti akan menguji data-data tentang peran politik NU dalam mempertahankan Pancasila dan kedaulatan Negara Kesatuan Republik Indonesia (NKRI) ditengah maraknya wacana khilafah Negara Islam (NI).

Analisis komparatif: yaitu suatu usaha mencari pemecahan melalui analisa hubungan sebab akibat yakni faktor-faktor yang berhubungan dengan situasi dan fenomena yang diteliti dengan membandingkan satu sama lainnya, menutup kemungkinan analisis ini akan menghasilkan modifikasi teori (Surakhmad 1982, 143).

\section{Peran Politik NU dalam Mempertahankan Pancasila dan Kedaulatan Negara Kesatuan Republik Indonesia}

\section{Peran NU dalam Perumusan Pancasila}

Pancasila yang akomodatif dalam konteks sila Ketuhanan tersebut mewujudkan tatanan negara yang unik dalam aspek hubungan agama dan negara. Dalam arti, negara Indonesia bukanlah negara sekuler dan bukan pula negara Islam, melainkan negara yang berupaya mengembangkan kehidupan beragama dan keagamaan (Wasid 2010). Jika saat ini ada sebagian kelompok Islam yang menolak Pancasila, bisa dikatakan dengan tegas bahwa mereka tidak ikut berjuang merumuskan berdirinya pondasi dan dasar negara ini. Peran K. Wahid Hasyim bukan hanya mampu menjabarkan Pancasila secara teologis dan filosofis terhadap rumusan awal yang diajukan oleh Soekarno pada 1 Juni 1945, tetapi juga menegaskan bahwa umat Islam Indonesia sebagai mayoritas menunjukkan sikap inklusivitasnya, sehingga Pancasila merupakan dasar negara yang merepresentasikan seluruh bangsa Indonesia.

Konsistensi Menjaga Persatuan untuk Memperkokoh Integritas bangsa Negara Kesatuan Republik Indonesia dan Pancasila selain telah terbukti mampu menjadi perekat bangsa sejak kemerdekaan hingga sekarang, juga mampu menjadi wadah dakwah Islam Nusantara secara luas. Pertumbuhan muslim di kawasan-kawasan mayoritas non muslim juga semakin meningkat. Namun demikian, di tengah perjalanan sejarah tantangan disintegrasi bangsa terkadang bermunculan, bahkan wacana mendirikan negara di dalam negara terus mengemuka. Sebab itu, internalisasi nilai-nilai kebangsaan, khususnya terkait Negara Kesatuan Republik Indonesia dan Pancasila sebagai upaya final dalam kehidupan berbangsa dan bernegara merupakan keharusan.

Berkenaan dengan itu perlu disadari, bahwa penerimaan Pancasila sebagai falsafah kehidupan berbangsa dan bernegara bagi NU telah sesuai dengan spirit piagam Madinah yang digagas oleh Rasulullah yang berhasil menyatukan masyarakat yang plural dalam satu kesatuan negeri Madinah. Sebagaimana diriwayatkan Ibn Ishaq dalam al-Sirah al-Nabawiyah (Ibn Hisyam 1994) 
tentang Piagam Madinah di antaranya menyatakan:

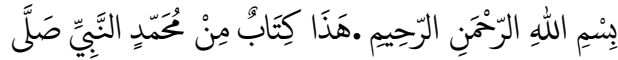

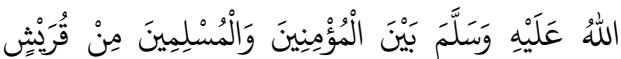

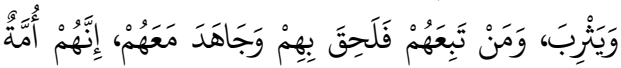

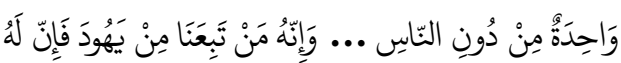

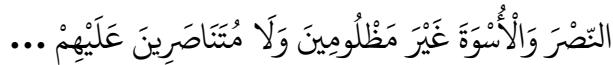

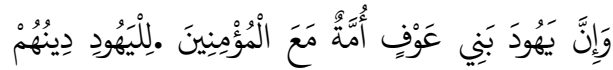

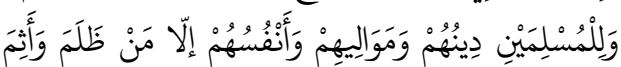

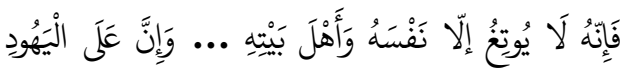

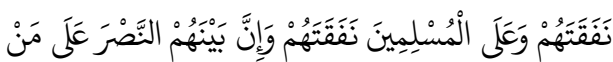

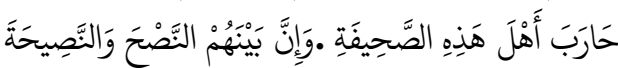

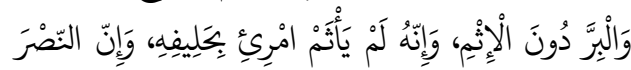

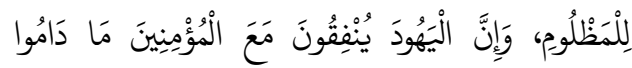

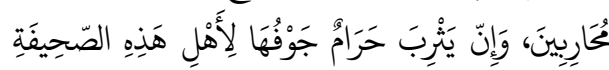

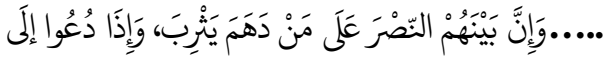

$$
\begin{aligned}
& \text { صُلْحَ يُصَالِحونَهُ....... }
\end{aligned}
$$

Dalil di atas menjadi dasar hasil Keputusan Bahtsul Masail Maudhu'iyah PWNU Jawa Timur Tentang "Islam Nusantara" di Universitas Negeri Malang pada tanggal 13 Februari 2016: 87 yang reverensinya diambil dari kitab: (a) Al-Hawi alKabir, XIV/330. (b) Risalah al-Qusyairiyah, I/103. (c). Ihya 'Ulum ad-Din, II/212. (d). Al-Majalis asSaniyyah, (Berut: Dar al-Fikr, 1956).

Piagam Madinah memberikan spirit, bahwa Nabi Muhammad menyatukan warga yang multi etnis dan multi agama menjadi ummah wahidah (satu kesatuan bangsa). Semua warga punya kedudukan yang sederajat, sama-sama berhak mendapatkan jaminan keamanan, melakukan aktifitas ekonomi, mengaktualisasikan agama, sama-sama berkewajiban untuk saling memberi nasehat dan berbuat kebaikan, menjaga keamanan serta integritas Madinah sebagai satu kesatuan negeri menghadapi ancaman dari luar.
Selain itu, untuk memupuk persatuan di tengah masyarakat yang plural perlu ditanamkan sikap menghargai perbedaan dan menjaga hak antarsesama, di antaranya dengan: a) Menghargai ajaran agama lain, b) Melestarikan budaya dari suku dan agama apapun selama tidak bertentangan dengan syariat, c) Mengapresiasi kebaikan/kelebihan orang lain dan mengakui kekurangan diri sendiri, d) Menghindari cacimaki terhadap orang lain karena alasan perbedaan, e) Menghindari anggapan menjadi orang yang paling baik dan menganggap orang lain tidak baik, sehingga mengabaikan kewajiban berbuat baik, f) Membiasakan berbuat kebajikan terhadap siapapun, g) Memprioritaskan penanaman nilai-nilai agama secara utuh dan mendalam di lingkungan internal Ahlussunah wal Jamaah.

Sejak Pancasila dijadikan dasar ideologi formal Republik Indonesia pada tahun 1945 oleh Soekarno, Pancasila menjadi bagian perdebatan politik yang tak terelakan oleh Politikus dan Agamawan, khususnya NU. Pada tahun 19781985 telah terjadi ideologisasi pancasila yang diinstruksikan oleh Soeharto, dan kemudian menimbulkan perdebatan yang luar biasa di kalangan tokoh dan gerakan ideologi Islam. Insiden politik semacam itu sempat terulang kembali pada tahun 1990 di negeri ini, yakni mengenai perdebatan ideologi. Sebenarnya sumber perdebatan itu adalah karena masih belum adanya konsensus mengenai relasi Islam dan negara, khususnya mengenai sistem negara apa yang akan dipakai untuk membangun Indonesia, apakah berasaskan Islam atau sekuler. Masalah relasi agama dan negara merupakan salah satu hal yang penting dalam pandangan $\mathrm{NU}$ mencari pola idial untuk negara Indonesia.

Pada tahun 1945 NU menerima adanya negara berideologi Pancasila, kurang lebihnya negara dari kategori dar shulh atau negara damai, bukan negara Islam dan tidak pula menentang Islam. Dalam konstituante di tahun 1958-1959 NU memperjuangkan berlakunya syari'at Islam 
dalam undang-undang negara (berarti membuat negara Islam), di tahun 1959 NU menerima dekrit presiden Soekarno untuk memberlakukan kembali Undang-Undang Dasar 1945, dan di tahun 1983-1984 NU menerima Pancasila sebagai satu-satunya asas bagi organisasi politik dan organisasi kemasyarakatan. Penerimaan lain-lainnya adalah dalam konteks Republik Indonesia sebagai Dār al-șulh, sedangkan "perjuangan" di Konstituante sebagai komitmen NU kepada idealisme Dār al-Islām, NU mempunyai gagasan mengaplikasikan syari'at melalui legislasi undang-undang negara. Dengan ungkapan lain sikap NU untuk mendirikan Dār al-Islām pernah dilakukan, karena memang demikianlah perintah keagamaan yang harus diikuti.

Dalam sejarah ke-Indonesia-an, Pancasila merupakan dasar negara yang dirumuskan oleh founding fathers bangsa, ini tidak terlepas dari keterkaitan tokoh ulama' Indonesia pada saat itu, terutama ulama NU, seperti KH. Hasyim Asy'ari, KH. Wahab Hasbullah, KH. Wahid Hasyim dan Ulama lainnya. Jadi tidak dipungkiri bahwa Pancasila merupakan ideologi yang bersumber dari nilai-nilai Islam itu sendiri. Menurut $\mathrm{KH}$. Abdurahman Wahid (Gus Dur) Pancasila adalah ideologi yang mendukung sistem demokrasi, sehingga sering disebut sebagai demokrasi Pancasila, yaitu demokrasi secara Islam. KH. Abdurahman Wahid berpendapat bahwa Pancasila adalah hasil dari kompromi-kompromi politik yang ingin menjaga keutuhan negara Indonesia sekaligus memungkinkan semua warganya bisa hidup bersama-sama secara harmoni, dengan menerima semua aspek kekayaan tradisi yang sudah ada. Menurutnya itu merupakan langkah konkrit realistis secara politik bila melihat dari pluralitas agama di Indonesia (Wahid 1999, 76).

Filsafat politik yang dijalankan NU sangat menghargai hak dan menjunjung tinggi derajat martabat masyarakat Indonesia, dan ia mampu mengkombinasikan antara kesalehan ajaran Islam dan kebebasan hak individu. Dengan demikian segala bentuk sekterianisme, eksklusifisme, dan primordialisme harus dihilangkan, dan menjunjung tinggi hak setiap individu bahwa semua warga memiliki derajat yang sama, tidak peduli asal usul agama, ras, etnis, bahasa, adat dan jenis kelaminnya. Menurut NU bahwa prinsip menjalankan ketatanegaraan dalam berbangsa, bernegara dan beragama adalah mengimplentasi kan nilai-nilai universal Islam, tidak hanya bertolak pada segi formalistiknya saja (Siddiq 1985, 172; Suroso 1987, 93; Wasid 2010, 67). Dengan menerapkan nilai-nilai Islam, maka bisa disebut telah memperjuangkan Islam. Islam juga tidak hanya dibaca dari segi doktrinal saja, tetapi juga dilihat dari segi nilai spirit dan ruhnya sebagai langkah pendewasaan dalam menyikapi kompleksitas problem di Indonesia.

Upaya mencamtumkan kembali isi Piagam Jakarta ke dalam batang tubuh UUD 1945 oleh sebagian gerakan Islam pada sidang tahunan MPR tahun 2000 dan tahun 2002. Bagi organisasi NU tentang persoalan dilema Pancasila, relasi antara Agama dan Negara itu sudah dianggap selesai pada Muktamar NU ke-27 di Situbondo pada tahun 1984 dengan menerima ideologi Pancasila sebagai asas bangsa Indonesia dan memulihkan kembali NU sebagai organisasi keagamaan sesuai dengan Khittah 1926.

Dalam keputusan deklarasi itu jelaslah bahwa NU mengakui dan mendukung penuh Pancasila sebagai dasar dan falsafah negara Republik Indonesia, yang pengamalannya bisa menjadi perwujudan dari upaya umat Islam untuk menjalankan syariat agamanya (A. Abdullah 2011; Goncing 2015; Marijan 1992; PBNU 1983). NU dengan tegas dan jelas memisahkan antara negara dengan agama. Pancasila adalah dasar negara, bukan agama, keberadaan Pancasila tidak dapat menggantikan agama atau dipergunakan untuk menggantikan kedudukan agama,meski begitu, bukan berarti agama tidak berurusan dengan negara. Dalam deklarasi itu malah dinyatakan bahwa adalah kewajiban NU - 
atau dengan kata lain kewajiban umat beragama- untuk mengamankan tafsir yang benar tentang Pancasila dan sekaligus pengamalannya yang murni dan konsekuen agar sesuai dengan upaya umat Islam Indonesia dalam menjalankan syariat agamanya.

\section{Peran NU dalam Menjaga Kedaulatan Wilayah Negara Kesatuan Republik Indonesia (NKRI)}

Berakhirnya Perang Dingin dan berkembangnya fenomena globalisasi, mendorong perubahan terhadap konsentrasi keamanan negara. Secara tradisional, keamanan didefinisikan dari perspektif geo-politik, dengan menekankan pada aspek-aspek seperti strategi penangkalan (detterence), perimbangan kekuatan (power balancing), dan strategi militer. Dengan segala dampak menguntungan dan merugikan dari globalisasi, yang terproses dalam dimensi yang beragam pula, menuntut negara untuk lebih memperhatikan keamanan dari perpektif nonkonvensional (Moesa 2007, 61). Dimana aspekaspek ideologi, ekonomi, budaya, sosial-politik, teknologi, militer, pertahanan negara, dan seterusnya, sebagai dimensi yang mampu menciptakan ancaman.

Ancaman yang harus kita tanggulangi dalam rangka mempertahankan keutuhan Negara Kesatuan Republik Indonesia adalah setiap upaya dan kegiatan, baik dari dalam negeri maupun luar negeri yang dinilai mengancam atau membahayakan kedaulatan negara, keutuhan wilayah negara, dan keselamatan segenap bangsa. Di tengah era globalisasi yang melahirkan ideologi kapitalisme, kedaulatan wilayah negara Republik Indonesia menghadapi tantangan dari upaya-upaya pencaplokan pulau-pulau terpencil oleh negara lain. Hal ini dikarenakan wilayah Indonesia baik darat maupun perairan memiliki kekayaan alam yang melimpah sehingga menjadi sasaran negara lain.
Dampak globalisasi dan eforia demokrasi yang kebablasan ini telah membuka seluasluasnya pintu kebebasan, bahkan kebebesan yang menjurus pada tindakan makar terhadap negara pun leluasa bergerak. Namun bagi NU, NKRI (Negara Kesatuan Republik Indonesia) merupakan upaya final dari perjuangan seluruh penduduk Indonesia-termasuk umat Islam di dalamnya-dalam mendirikan negara (Anam 2010, 9). NKRI (Negara Kesatuan Republik Indonesia) adalah negara yang sah menurut hukum Islam, yang menjadi wadah berkiprah melaksanakan dakwah yang akomodatif dan selektif, serta bertaqwa sesempurna mungkin, tidak usah mencari atau membuat negara yang baru (Miri dan Said 2005). Bahkan merujuk Resolusi Jihad 22 Oktober 1945, mempertahankan dan menegakkan NKRI (Negara Kesatuan Republik Indonesia) menurut hukum agama Islam adalah wajib, termasuk sebagai satu kewajiban bagi tiap-tiap muslim, dan jihad $f i$ sabilillah (Muzadi 2007, 31-7). Karena itu, NU mempunyai tanggung jawab terhadap kehidupan kebangsaan dan kenegaraan, baik dahulu, sekarang, maupun masa mendatang.

Terkait tanggung jawab tersebut, melalui Muktamar ke-29 di Cipasung Tasikmalaya pada 1 Rajab 1415 H/ 4 Desember 1994 M, NU mengeluarkan Keputusan Muktamar Nahdlatul Ulama No. 02/MNU-29/1994 tentang Pengesahan Hasil Sidang Komisi Ahkam/Masail Diniyah, yang di antaranya terkait dengan pandangan dan tanggung jawab NU terhadap kehidupan Kebangsaan dan Kenegaraannya, diantaranya pandangan NU tersebut adalah:

Pertama, NU menyadari bahwa kehidupan berbangsa dan bernegara di mana sekelompok orang yang oleh karena berada di wilayah geografis tertentu dan memiliki kesamaan, kemudian mengikatkan diri dalam satu sistem dan tatanan kehidupan merupakan "realitas kehidupan" yang diyakini merupakan bagian dari kecenderungan dan kebutuhan yang fitri dan manusiawi. Kehidupan berbangsa dan bernegara 
adalah perwujudan universalitas Islam yang akan menjadi sarana bagi upaya memakmurkan bumi Allah dan melaksanakan amanat-Nya sejalan dengan tabiat atau budaya yang dimiliki bangsa dan wilayah itu.

Kedua, kehidupan berbangsa dan bernegara seyogyanya merupakan langkah menuju pengembangan tanggung jawab kekhilafahan yang lebih besar, yang menyangkut "kehidupan bersama" seluruh manusia dalam melaksanakan amanat Allah., mengupayakan keadilan dan kesejahteraan manusia, lahir dan batin, di dunia dan di akhirat.

Ketiga, kehidupan berbangsa dan bernegara haruslah dibangun atas dasar prinsip ketuhanan, kedaulatan, keadilan, persamaan dan musyawarah. Dengan demikian maka pemerintah (umara') dan ulama' sebagai pengemban amanat kekhilafahan serta rakyat adalah satu kesatuan yang secara bersama-sama bertanggung jawab dalam mewujudkan tata kehidupan bersama atas dasar prinsip-prinsip tersebut.

Keempat, umara' dan ulama dalam konteks di atas, merupakan pengemban tugas khilafah dalam arti menjadi pengemban amanat Allah dalam memelihara dan melaksanakan amanatNya dan dalam membimbing masyarakat sebagai upaya memperoleh kesejahteraan dan kebahagiaan hidup yang hakiki. Dalam kedudukan seperti itu, pemerintah dan ulama merupakan ulil amri yang harus ditaati dan diikuti oleh segenap warga masyarakat. Sebagaimana firman Allah. yang artinya: "Hai orang-orang yang beriman taatilah Allah dan taatilah Rasul-Nya dan ulil amri di antara kamu. Kemudian jika kamu berlainan pendapat tentang sesuatu, maka kembalikanlah ia kepada Allah (al-Qur'an) dan Rasul (Sunnahnya), jika kamu benar-benar beriman kepada Allah dan hari kemudian. Yang Demikian itu lebih utama (bagimu) dan lebih baik akibatnya. (QS. al-Nisa': 59) (Miri dan Said 2005, 77).
Dalam pandangan NU bagaimana agar keutuhan Negara Kesatuan Republik Indonesia tetap terjaga, salah satu caranya adalah kita sebagai warga negara berpartisipasi dalam upaya menjaga keutuhan wilayah dan bangsa Indonesia. Berpartisipasi artinya turut serta atau terlibat dalam kegiatan-kegiatan yang dapat menjaga keutuhan wilayah dan bangsa Indonesia (Masdar 1999, 17). Pada periode 1998-2009, Indonesia berada dalam kondisi krisis multidimensi dan ancaman perpecahan dalam (disintegrasi) bangsa dan juga ancaman muncul dari luar seperti klaim atau aneksasi pulau-pulau kecil Indonesia oleh negara lain. negara. Dalam perjalanan sejarah pemikiran dan kebijakan $\mathrm{NU}$ di era reformasi (1998-2009) menunjukkan bahwa NU berperan penting dalam menjaga kedaulatan wilayah Negara Kesatuan Republik Indonesia (Setiawan 2010).

\section{Penolakan NU atas Konsep Khilafah di Indonesia}

Di Indonesia, benih ide khilafah sudah ada sejak awal kemerdekaan tahun 1945, baik yang bersifat konstitusional, seperti Majelis Konstituante, atau bersifat militer, seperti dalam kasus DI/TII, yang berusaha mendirikan Negara Islam (NI) dan menolak Pancasila. Era reformasi tahun 1998 yang memberikan ruang kebebasan publik, menjadikan isu khilafah di Indonesia kian vulgar dan menemukan momentumnya. Pembicaraan-pembicaraan yang mewacanakan isu khilafah semakin intens dan terbuka dikampanyekan, baik lewat opini-opini pemikiran maupun gerakan nyata. Seperti mewacanakan Islam sebagai solusi dan edeologi alternatif mengusahakan bentuk pemerintahan Negara Indonesia dari Negara kesatuan berformat Republik menjadi khilafah, demikian juga wacana yang sangat santer untuk merubah konstituisi Negara mulai dari Undang-Undang Dasar 1945 sampai pada hukum positif baik hukum pidana atau hukum perdata diinginkan 
untuk diganti total menjadi hukum syariat Islam seutuhnya.

Perspektif NU tentang konsep khilafah ini tegas, bahwa NU tidak sepakat dengan wacana sebagian organisasi Islam di Indonesia yang menginginkan terbentuknya khilafah Islamiah di Indonesia. Menurut KH. Said Agil Siroj yang juga sebagai ketua PBNU, menjelaskan bahwa negara khilafah bukanlah solusi untuk pemecahan persoalan bangsa. NU menolak bentuk aliran dan bentuk negara serta khilafah apapun namanya, kecuali khilafah nasionalis (Hakim 2004). KH. Said Agil Siroj menyatakan, bahwa konsep negara Indonesia jauh lebih baik dibandingkan negara-negara Islam lain termasuk negara Islam di Timur Tengah. Sebab Indonesia yang saat ini merupakan negara dengan komitmen dengan amanah keagamaan dan komitmen kebangsaan yang menjadikan Indonesia tidak mudah untuk dipecah belah oleh pihak lain, negara-negara Islam yang berada dikawasan Timur Tengah yang akhirnya justru hancur dikarenakan tidak memperhatikan komitmen kebangsaan. Maka apabila Indonesia berubah menjadi konsep khilafah, Indonesia akan hancur, porak poranda akibat adanya konflik yang berkepanjangan antar ormas agama dan aliran yang berada di Indonesia.

Konflek berkepanjangan akan muncul di Indonesia dikarenakan sejarah sudah membuktikan bahwa keberadaan umat Islam di Indonesia dengan yang berada di Timur Tengah berbeda konteks dan historisnya, memunculkan kembali konsep khilafah sama halnya membuat peradaban Islam itu sendiri lari dari konteks Islam yang sebenarnya. Banyak negara Islam khususnya di Timur Tengah akibat tidak mempunyai komitmen untuk menyelamatkan bangsanya, sehingga negaranya hancur. Oleh karenanya NU berkomitmen untuk menjaga Negara Kesatuan Republik Indonesia (NKRI) ini tetep berasaskan Pancasila dan NU senantiasa mengajak segenap bangsa Indonesia khususnya umat Islam untuk sama-sama menjaga kedaulatan negara Indonesia ini dalam bingkai Pancasila dan NKRI. Terutama dari pengaruh paham ekstrim yang coba ditularkan kelompok militan Islamic State of Iraq and Sham (ISIS) yang juga mencoba memengaruhi pemikiran umat Islam Indonesia terutama kalangan muda untuk mau bergabung. Dalam perspektif NU bahwa organisasi yang digerakkan meluai wadah Islamic State of Iraq and Sham (ISIS) bukanlah gerakan atas nama Agama, justru sebaliknya Islamic State of Iraq and Sham (ISIS) semakin mencoreng dan merontokkan kebudayaan Islam.

Terkait ormas Islam yang senantiasa mewacanakan terhadap gagasan Negara Islam (NI), yang dikembangkan oleh beberapa partai politik yang menggunakan nama Islam. Pendirian NU sebagaimana tertuang dalam keputusan Muktamar NU tahun 1935 di Banjarmasin (Borneo Selatan), menjelaskan bahwa wajib hukumnya secara syari'at Islam, umat Islam untuk menjaga kerajaan Hindia-Belanda (negara Indonesia saat ini), karena adanya dua illat hukum (sebab hukum). Sebab pertama, karena kaum muslimin merdeka dan bebas menjalankan ajaran Islam. Sebab kedua, dikarenakan dahulu di kawasan tersebut telah terdapat kerajaan Islam (Taimiyyah 1988, 79).

Dalam pendapat pemikir ini, hukum Islam (fiqh) memperkenankan adanya pimpinan berbilang (ta'addud al-a'immah), yang berarti pengakuan akan kenyataan bahwa kawasan dunia Islam sangatlah lebar di muka bumi ini, hingga tidak dapat dihindarkan untuk dapat menjadi efektif (shaukah) (Taimiyyah 1988).

Menurut Ibn Taimiyyah konsep adanya pimpinan umat yang hanya khusus berlaku bagi kawasan yang bersangkutan, berdasar pada firman Allah; "Sesungguhnya Aku telah menciptakan kalian dari jenis laki-laki dan perempuan dan Aku jadikan kalian berbangsa- 
bangsa dan bersuku-suku bangsa, agar kamu sekalian saling mengenal" (Taimiyyah 1988).

Berdasarkan keputusan Muktamar NU di Banjarmasin tahun 1935 di atas, NU dapat menerima kenyataan tentang kedudukan negara dalam pandangan Islam, NU dan banyak organisasi Islam lainnya, berpendapat tidak perlu di Indonesia ini konsep khilafah dalam bentuk Negara Islam (NI). Ini disebabkan oleh heterogenitas yang sangat tinggi di antara para warga negara yang berada di Indonesia, di samping kenyataan ajaran Islam menjadi tanggungjawab masyarakat setempat, tidak menjadi tanggung jawab negara. Pandangan NU ini berdasarkan pada kenyataan bahwa Islam tidak memiliki ajaran formal yang baku tentang negara, yang jelas ada adalah mengenai tanggung jawab masyarakat untuk melaksanakan syariat Islam.

Sebuah masyarakat yang secara moral berpegang dan dengan sendirinya melaksanakan syariat Islam, tidak lagi memerlukan kehadiran sebuah Negara Agama atau Negara Islam (NI), seperti yang dibuktikan para sahabat di Madinah setelah Nabi Muhammad wafat. Inilah yang membuat mengapa NU tidak memperjuangkan sebuah Negara Islam (NI) di Indonesia atau menjadi NII (Negara Islam Indonesia). Kemajemukan (heterogenitas) yang tinggi dalam kehidupan bangsa kita, membuat kita hanya dapat bersatu dan kemudian mendirikan negara, yang tidak berdasarkan agama tertentu, kenyataan inilah yang sering dikacaukan oleh orang yang tidak mau mengerti bahwa mendirikan sebuah Negara Islam (NI) tidak wajib bagi kaum muslimin di Indonesia, tapi mendirikan masyarakat yang berpegang kepada ajaran-ajaran Islam adalah sesuatu yang wajib. Telah disebutkan di atas fatwa Ibn Taimiyyah, tentang kebolehan Imam berbilang (ta'addud al-imam) yang berarti tidak adanya keharusan mendirikan Negara Islam (NI), padahal kalau dikaji secara mendalam bahwa selama ini NU tidak banyak memakai pendapat Ibn Taimiyyah, namun dalam hal pembentukan negara justru NU lah yang menggunakan pendapat beliau dan ormas yang beraliran keras tidak memakai pendapat Ibn Taimiyyah yang notabene dalam segala perilaku ibadah mereka memakai pendapat Ibn Taimiyyah yang bermazhab Hambali. Di sisi lain pemikiran Ibn Taimiyyah banyak digunakan oleh bangsa yang berkuasa di Saudi Arabia bersama-sama dengan ajaran-ajaran Mazhab Hambali (disebutkan juga dalam bahasa Inggris Hambalite School), yang secara de facto melarang orang bermazhab lain.

Kenyataan ini tentu saja membuat orangorang NU bersikap reaktif terhadap mazhab tersebut. Tentu saja hal itu secara resmi tidak dilakukan, karena sikap Saudi Arabia terhadap mazhab-mazhab non-Hambali juga tidak bersifat formal. Dengan kata lain, pertentangan pendapat antara "pandangan kaum Wahabi" yang secara de facto demikian keras terhadap mazhabmazhab lain itu, menampilkan reaksi tersendiri yang tidak kalah kerasnya. Ini adalah contoh dari sikap keras yang menimbulkan sikap yang sama pada "pihak seberang". Contoh dari sikap saling menolak, dan saling tidak mau mengalah itu membuat gagasan membentuk Negara Islam (NI) di negara kita menjadi sebuah Negara Islam Indonesia (NII), sebagai sebuah utopia yang terdengar sangat indah, namun sangat meragukan dalam kenyataan. Ini belum kalau pihak nonmuslim ataupun pihak kaum Muslimin nominal (kaum abangan), tidak berkeberatan atas gagasan mewujudkan negara Islam tersebut.

Jadi gagasan yang semula tampak indah itu, pada akhirnya akan dinafikan sendiri oleh bermacam-macam sikap para warga negara, yang hanya sepakat dalam mendirikan negara bukan agama. Inilah yang harus dipikirkan sebagai kenyataan sejarah. Kalaupun toh dipaksakan -sekali lagi- untuk mewujudkan gagasan Negara Islam (NI) di negara kita ini, 
maka yang akan terjadi hanyalah serangkaian pemberontakan bersenjata seperti yang terjadi di negara kita tahun-tahun 1950-an. Apakah deretan pemberontakan bersenjata seperti itu, yang ingin kita saksikan kembali dalam sejarah modern bangsa kita. Ini prinsip yang jelas, tapi sulit dilaksanakan.

Dari gamabaran tersebut di atas, maka NU melalui keputusan Musyawarah Nasional Alim Ulama yang diadakan pada tanggal 1-2 November 2014 di Jakarta memutuskan beberapa poin penting sehubungan dengan khilafah yaitu:

Pertama, Islam sebagai agama yang komprehensif (dīn shāmil al-kāmil) tidak mungkin melewatkan masalah negara dan pemerintahan dari agenda pembahasannya. Kendati tidak dalam konsep utuh, namun dalam bentuk nilainilai dan prinsip-prinsip dasar (mabadi asasiyyah), Islam telah memberikan panduan (guidance) yang cukup bagi umatnya.

Kedua, mengangkat pemimpin (nashb alimām) wajib hukumnya, karena kehidupan manusia akan kacau (fawdla/chaos) tanpa adanya pemimpin.

Ketiga, Islam tidak menentukan apalagi mewajibkan suatu bentuk negara dan sistem pemerintahan tertentu bagi para pemeluknya. Umat diberi kewenangan sendiri untuk mengatur dan merancang sistem pemerintahan sesuai dengan tuntutan perkembangan kemajuan zaman dan tempat. Namun yang terpenting suatu pemerintahan harus bisa melindungi dan menjamin warganya untuk mengamalkan dan menerapkan ajarankan agamanya dan menjadi tempat yang kondusif bagi kemakmuran, kesejahteraan dan keadilan.

Keempat, khilafah sebagai salah satu sistem pemerintahan adalah fakta sejarah yang pernah dipraktikkan oleh al-Khulafa' al-Rasyidun. AlKhilafah al-Rasyidah adalah model yang sangat sesuai dengan eranya; yakni ketika kehidupan manusia belum berada di bawah naungan negara-negara bangsa (nation states). Masa itu umat Islam sangat dimungkinkan untuk hidup dalam satu sistem khilafah. Pada saat umat manusia bernaung di bawah negara-negara bangsa (nation states) maka sistem khilafah bagi umat Islam sedunia kehilangan relevansinya. Bahkan membangkitkan kembali ide khilafah pada masa kita sekarang ini adalah sebuah utopia.

Negara Kesatuan Republik Indonesia (NKRI) adalah hasil perjanjian luhur kebangsaan di antara anak bangsa pendiri negara ini. NKRI dibentuk guna mewadahi segenap elemen bangsa yang sangat mejemuk dalam hal suku, bahasa, budaya dan agama. Sudah menjadi kewajiban semua elemen bangsa untuk mempertahankan dan memperkuat keutuhan NKRI. Oleh karena itu, setiap jalan dan upaya munculnya gerakan-gerakan yang mengancam keutuhan NKRI wajib ditangkal. Sebab akan menimbulkan mafsadah yang besar dan perpecahan umat.

Umat Islam tidak boleh terjebak dalam simbol dan formalitas nama yang tampaknya islami (PBNU 1983), tetapi wajib berkomitmen pada substansi segala sesuatu. Dalam adagium yang populer di kalangan para ulama NU dikatakan: "yang menjadi pegangan pokok adalah substansi, bukan simbol atau penampakan lahiriah. "لابالإسم بلمسمى العرة" yang menjadi pegangan pokok adalah sesuatu yang diberi nama, bukan nama itu sendiri". Dengan demikian, memperjuangkan tagaknya nilai-nilai substantif ajaran Islam dalam sebuah negara apapun nama negara itu, Islam atau bukan - jauh lebih penting dari pada memperjuangkan tegaknya simbol-simbol negara Islam.

Bagi organisasi NU sebetulnya diskusi tentang relasi agama vis- $a$-vis negara, atau Islam vis-a-vis Pancasila, sudah dapat dianggap selesai. Keputusan Muktamar NU ke-27 di Situbondo pada 
tahun 1984 telah mengakhiri perdebatan ini. Muktamar yang yang berlangsung tanggal 8-12 Desember 1984 itu mengukuhkan keputusan Musyawarah Alim Ulama Nasional NU 1983 yang memutuskan untuk menerima Pancasila sebagai satu-satunya asas dan memulihkan kembali NU menjadi organisasi keagamaan sesuai dengan Khitthah (semangat) 1926. Melalui forum keagamaan kultural Bahstul Masa'il, ulama NU mampu menemukan rumusan yang tepat untuk mengurai dan memberikan kesimpulan tentang relasi Islam dan Pancasila dari perspektif keagamaan, khsususnya pendekatan fiqh.

NU adalah organisasi kemasyarakatan dan keagamaan pertama yang menuntaskan penerimaannya atas ideologi Pancasila. NU bukan hanya pertama menerima, tetapi juga yang paling mudah menerima Pancasila. Muhamadiyyah menerima Pancasila setelah terbitnya UU Nomor 8 Tahun 1985 tentang Organisasi Kemasyarakatan. Keputusan paradigmatik penerimaan NU atas Pancasila dan keberadaan negarabangsa dikenal dengan "Deklarasi tentang Hubungan Pancasila dengan Islam". Deklarasi ini merupakan simpul dan titik akhir dari pembahasan keagamaan (bahth al-masāiil) ulama NU tentang Pancasila sebagai ideologi negara, tentang wawasan kebangsaan, dan posisi Islam dalam negara-bangsa. Dalam deklarasi ini, jelas bahwa NU mengakui dan mendukung penuh Pancasila sebagai dasar dan falsafah negara Republik Indonesia, yang pengamalannya bisa menjadi perwujudan dari upaya umat Islam untuk menjalankan syari'at agamanya. NU dengan tegas dan jelas memisahkan antara negara dengan agama. Pancasila adalah dasar negara, bukan agama. Keberadaan Pancasila tidak dapat menggantikan agama atau dipergunakan untuk menggantikan kedudukan agama, meski begitu, bukan berarti agama tidak berurusan dengan negara. Dalam deklarasi itu malah dinyatakan bahwa adalah kewajiban bagi
NU-atau dengan kata lain kewajiban umat beragama-untuk mengamankan tafsir yang benar tentang Pancasila dan sekaligus pengamalannya yang murni dan konsekuen agar sesuai dengan upaya umat Islam Indonesia dalam menjalankan syari'at agamanya. Ini artinya NU memposisikan agama sebagai landasan moral-etik bagi negara agar negara tetap berada dalam kontrol agama untuk menegakkan keadilan dan selalu berorientasi pada kesejahteraan dan kemaslahatan rakyatnya, keputusan deklarasi ini menjelaskan posisi agama dan negara yang terpisah, tetapi secara relasional mempunyai simbiosis yang mutualistik dalam mewujudkan nilai-nilai keadilan, kemanusiaan, kemaslahatan, kerahmatan, dan pembebasan bagi umat manusia (PBNU 1979, 61).

Keputusan penting dan mendasar ini dalam deklarasi ini, banyak diilhami oleh pemikiran K.H. Achmad Shiddiq, Rais Aam Syuriyah PBNU saat itu. Pemikiran Kyai Achmad Shiddiq ini sekaligus juga merupakan argumen teologis dan fiqhiyyah atas sikap keagamaan NUterhadap kenyataan negara-bangsa modern dewasa ini. Beberapa simpul pemikiran Kyai Achmad Shiddiq yang utama adalah 1) Mendirikan negara dan membentuk kepemimpinan negara untuk memelihara keluhuran agama dan mengatur kesejahteraan duniawi wajib hukumnya. 2) Kesepakatan bangsa Indonesia untuk mendirikan Negara KesatuanRepublik Indonesia adalah sah dan mengikat semua pihak termasuk Islam. 3) Hasil dari keputusan yang sah itu, yaitu Negara Kesatuan Republik Indonesia, adalah sah dilihat dari pandangan Islam, sehingga harus dipertahankan dan dilestarikan eksistensinya.

Sebagaimana termaktub dalam makalahnya, pemikiran Kyai Achmad Shiddiq ini dilatarbelakangi oleh dua landasan yang berkait, Pertama, landasan historis; dinyatakan bahwa umat Islam tidak pernah absen dalam perjuangan menolak penjajahan dan menegak- 
kan serta mengisi kemerdekaan. Umat Islam senantiasa berada dalam garda terdepan dalam mengusir penjajah dan mengisi kemerdekaan yang diperolehnya. Kedua, landasan hukum; bahwa Allah Swt. telah mewajibkan amar ma'rûf nahy munkar bagi umat manusia. Kewajiban ini tentu saja tidak dapat dilakukan tanpa adanya kekuatan dan imamah (kepemimpinan politik) yang kuat dan mendukung. Atas dua landasan inilah, maka mendukung negara Pancasila menjadi wajib hukumnya sebagai konsekuensi dari perjuangan yang dilakukan oleh umat Islam di masa lalu. Konsekuensi dari penerimaan Pancasila sebagai satu-satunya asas ini, seperti juga ditegaskan oleh Kyai Achmad Shiddiq, memberikan arti bahwa wujud negara Republik Indonesia dengan Pancasila sebagai dasarnya merupakan upaya final seluruh bangsa, terutama kaum Muslimin, untuk mendirikan negara di wilayah Nusantara.

Nalar ideologi dan kebangsaan ulama NU ini sebetulnya tidak secara tiba-tiba muncul. Sejak perang kemerdekaan hingga perkembangan dewasa ini, yakni dalam menghadapi dua arus utama yang bertolak belakang antara menjadikan Islam sebagai dasar negara dan menolak Pancasila sebagai ideologi tunggal ini, NUselalu mengambil jalan tengah (tawassuț) dan peran strategis dalam pembentukan negara dan karakter bangsa. Dua bulan setelah Republik Indonesia diproklamasikan kemerdekaannya, tepatnya tanggal 22 Oktober 1945, Rais Akbar KH. M. Hasyim Asy'ari mengeluarkan fatwa "Resolusi Jihad” yang mewajibkan setiap orang (fardu 'ain) dalam radius $94 \mathrm{~km}$ untuk melakukan jihâd fiy sabïlillāh melawan Belanda, Belanda saat itu tiba kembali di tanah air untuk menjajah. Fatwa ini kemudian dikukuhkan sebagai Keputusan Muktamar NU ke-16 di Purwokerto, 26-29 Maret 1946. Bahkan jauh sebelum kemerdekaan, dalam Muktamar ke-11 di Banjarmasin, 9 Juni 1935, NU telah memberikan status hukum negara Indonesia yang saat itu masih dikuasai oleh
Pemerintah Penjajah Belanda dengan "negara Islam". Meskipun saat itu Indonesia masih dikuasai oleh Penjajahan Belanda, tetapi dalam sejarahnya Indonesia pernah dikuasai sepenuhnya oleh orang Islam dan orang Islam dapat secara bebas menjalankan syari'at keagamaannya. Dengan logika ini, maka mempertahankan kemerdekaan Indonesia dan mengisi kemerdekaan dengan persatuan-kesatuan, kedamaian, kerukunan, keutuhan dan lebih-lebih keadilan-kemanusiaan bagi seluruh rakyat bangsa dan negara menjadi sangat penting bagi NU (PBNU 1983, 12).

Dengan rangkaian ijtihad nalar politik keagamaan ini, "Deklarasai Hubungan Pancasila dan Islam" dirumuskan oleh ulama NU sebagai Keputusan Munas Alim Ulama NU tahun 1983 di Situbondo. Keputusan ini sebetulnya mengakhiri perdebatan paradigmatik tentang hubungan agama dan negara di Indonesia, sekaligus memperkuat basis teologis penerimaan $\mathrm{NU}$ atas kenyataan negara-bangsa (nation state) yang pluralistik dan demokratik. NU mendukung kenyataan ini sebagai ijtihad politikyang tepat.

Dengan meletakkan kunci masalah pada pengesahan hukum fiqh, NU mampu melakukan sebuah proses penyesuaian dengan tuntutan sebuah negara modern. Tuntutan ini tidak saja menyentuh pada kebutuhan eksistensial belaka, tetapi juga pada aras substansial-paradigmatik bagi tatanan kehidupan bersama yang rukun, damai, demokratis, menghargai pluralitas, dan senantiasa bertumpu pada kerangka dasar keadilan sosial. Tawassuț, tawāzun, ta'ādul, dan tasāmuḥmerupakan prinsip dasar bagi $\mathrm{NU}$ dalam menyelesiakan berbagai masalah kontemporer. Keberhasilan NU memberikan penyelesaian paradigmatik relasi agama dan negara ini mengindikasikan adanya pergeseran paradigma di kalangan NU sendiri dalam memandang kenyataan negara-bangsa. Baik pada aspek siyāsah, maupun aspek hukum dan peradaban, trans- 
formasi pemikiran di kalangan NU terus menggelinding.

Tidak diingkari bahwa masyarakat NU adalah masyarakat fiqh. Ini tidak lain karena masih dominannya kalangan Pesantren di jajaran NU, sementara paradigma pesantren identik dengan fiqh. Dengan kata lain, NU adalah pesantrenmakro, dan pesantren adalah NU-mikro. Akan tetapi mempertimbangkan pemikiran di atas, penulis kira tidak berlebihan jika dicatat bahwa di dalam kalangan $\mathrm{NU}$ tengah terjadi transformasi paradigma fiqh dari literalisme ke kontekstualisme, dari skripturalisme ke substansialisme, dan dari mazhabqawlike mazhab manhaji.

Oleh karena itu, anggapan yang menyatakan bahwa NU konservatif, ortodoks, mundur dalam berpikir, menutup pintu ijtihad, dan sejumlah stereotype lain yang memposisikan NU dalam kubangan "kejumudan" dan "ketertinggalan" kiranya segera dipertimbangkan kembali. NU memang tradisional, tetapi radikal dan kritis dalam merespons perkembangan zaman dan kenyataan sosial kekinian.

Berangkat dari nalar di atas juga, NU secara tegas menolak gagasan khilafah dan konsep Negara Islam di Indonesia, sikap ini sudah ditunjukan oleh $\mathrm{NU}$ pada masa Orde Baru dengan kehadiran Negara Islam Indonesia (NII) yang didirikan oleh Kartosuwiryo dan kawankawanya, Ulama NU memberikan keputusan fiqh kepada Kartosuwiryo sebagai pelaku bughat (pemberontakan kepada negara yang sah) akibat pemikiran dan gerakannya itu. Sikap penolakan konsep khilafah ini juga ditunjukkan oleh $\mathrm{NU}$ dengan adanya sikap pengakuan NU terhadap Pemerintahan yang sah dilakukannya pada Konferensi Nasional Alim Ulama NU di Cipanas pada 1954. Keputusan Konferensi yang kemudian dikukuhkan oleh Keputusan Muktamar NU ke-20 di Surabaya, 8-13 September 1954, memutuskan bahwa kedudukan Kepala Negara Republik Indonesia (Ir. Soekarno) sebagai waliy al-amri al-dlarûri bi al-syawkah (penguasa pemerintahan secara darurat sebab kekuasaannya, atau pemegang pemerintahan sementara (de facto) dengan kekuasaan penuh). Pada masa Orde Baru sudah jelas sikap NU mendukung penuh sistem pemerintahan berdasar Pancasila tidak berdasar khilafah. Dan di masa era Reformasi sikap NU menentang penuh terhadap gerakan-gerakan Islam Radikalisme yang memperjuangkan lagi terhadap keberadaan khilafah untuk mengganti Indonesia ini yang sudah jelas rukun antar warga dan bangsanya. KeputusanNU semua ini dilakaukan secara sadar untuk membentengi rongrongan pemberontak yang bermaksud menggantikan Pancasila sebagai dasar negara.

\section{Simpulan}

NU pimpinan Hadhratus Syaikh KH. Hasyim Asy'ari sangat menjunjung tinggi nilai-nilai kebangsaan, nasionalisme yang berdasar atas syari'at Islam ala Ahl al-Sunnah wal-Jamä'ah. Bukti sikap nasionalis yang tunjukkan NU adalah peristiwa dimana sebelum negara Republik Indonesia merdeka, para pemuda di berbagai daerah mendirikan organisasi bersifat kedaerahan, seperti Jong Cilebes, Pemuda Betawi, Jong Java, Jong Ambon, Jong Sumatera, dan sebagainya, akan tetapi Kyai-Kyai NU justru mendirikan organisasi pemuda bersifat nasionalis. Dari rahim NU juga lahir laskar-laskar perjuangan fisik, di kalangan pemuda muncul laskarlaskar hizbullāh (Tentara Allah) dengan panglimanya KH. Zainul Arifin seorang pemuda kelahiran Barus Sumatra Utara 1909, dan di kalangan orang tua sabïlillāh (Jalan menuju Allah Swt) yang di komandoi oleh KH. Masykur.

Bahwa perjuangan jihad ulama dalam mengusir penjajah Belanda sebenarnya adalah tuntunan ajaran agama Islam yang harus dilaksanakan setiap umat-Nya sebagai bentuk manivestasi rasa syukur terhadap Allah Swt yang maha kuasa. Menurut pandangan NU Jihad yang dilakukan oleh ulama dan santrinya ialah jihad 
membela tanah air, sebagai bentuk cinta tanah air (hubb al-wațan) yang dimaknai sebagai jihad fi sabïlillāh. Karena upaya mempertahankan dan menegakkan negara Republik Indonesia dalam pandangan hukum Islam merupakan bagian dari kewajiban agama yang harus dijalankan umat Islam. Jihad sebagai satu amalan besar dan penting dalam Islam dengan keutamaannya yang sangat banyak sekali tentunya menjadi kewajiban seorang muslim untuk melaksanakannya bila suatu saat diserang oleh orang kafir. Oleh karena itu para ulama NU dalam konteks melawan penjajah Belanda memutuskan bahwa hukum jihad mempertahankan tanah air Indonesia adalah wajib atas seluruh orang yang berada di wilayah negara Indonesia yang diserang musuh penjajah kafir Belanda.

Prinsip NU tentang mempertahankan kedaulatan dan keutuhan Negara Kesatuan Republik Indonesia (NKRI) adalah prinsip utama bagi umat Islam untuk menjaga keutuhan negara Indonesia pada saat ini. Hal ini semakin penting karena Indonesia tengah menghadapi persoalan serius yaitu kemungkinan terjadinya disintegrasi nasional. Muncul keinginan dari beberapa daerah untuk memisahkan diri dari NKRI perlu dilakukan upaya penyempurnaan Undang-Undang Otonomi Daerah sehingga aturan tersebut nantinya tidak mengilhami suatu daerah untuk memisahkan diri dari negara nasional. Aturan tersebut dibuat harus dengan didasari semangat menjaga kedaulatan dan keutuhan NKRI dan memajukan kesejahteraan masyarakat, bangsa dan negara Indonesia.

NU tidak sepakat dengan wacana yang menginginkan terbentuknya khilafah Islamiah di Indonesia. Menurut NU, negara khilafah bukan- lah solusi untuk pemecahan persoalan bangsa. NU menolak bentuk aliran dan bentuk negara serta khilafah apapun kecuali khilafah nasionalis. Bagi NU, konsep negara Indonesia jauh lebih baik dibandingkan negara-negara Islam lain termasuk negara Islam di Timur Tengah. Sebab Indonesia yang saat ini merupakan negara dengan komitmen dengan amanah keagamaan dan komitmen kebangsaan membuat Indonesia tak mudah untuk dipecah belah oleh pihak lain. Menurut pendapat NU ternyata negara-negara Islam Timur Tengah yang akhirnya justru hancur karena tidak memperhatikan komitmen kebangsaan. Bila Indonesia berubah menjadi konsep khilafah, maka NU mengkhawatirkan Indonesia akan hancur.

Akibatnya, justru membuat peradaban Islam itu sendiri lari dari konteks Islam yang sebenarnya. Banyak negara Islam khususnya di Timur Tengah akibat tidak mempunyai komitmen untuk menyelamatkan bangsanya, sehingga negaranya hancur. Untuk itu, NU mengajak segenap bangsa Indonesia khususnya umat Islam untuk sama-sama menjaga kedaulatan NKRI. Terutama dari pengaruh paham ekstrim yang coba ditularkan kelompok militan Islamic State of Iraq and Sham (ISIS) yang juga mencoba memengaruhi pemikiran umat Islam Indonesia terutama kalangan muda untuk mau bergabung. Menurut perspektif NU bahwa organisasi yang tergabung dalam Islamic State of Iraq and Sham (ISIS) bukanlah gerakan atas nama Agama, namun bahwa organisasi yang tergabung dalam Islamic State of Iraq and Sham (ISIS) adalah ormas yang bertentangan dengan agama dan mencoreng serta merontokkan kebudayaan Islam.]

\section{DAFTAR PUSTAKA}

Abdullah, Anzar. 2011. "Nahdatul Ulama and the Khittah Revitalization: A Futuristic Critical Reflection for the Largest Islamic Organization in Indonesia." Tawarikh: International Journal for Historical Studies 3(1): 95-108. http://journals.mindamas.com/index.php/tawarikh/article/view/398. 
Abdullah, Taufik, dan Abdurrachman Surjomihardjo. 1984. Ilmu Sejarah dan Historiografi; Arah dan Perspektif. Jakarta: Gramedia.

Anam, Choirul. 2010. Pemikiran K.H. Achmad Siddiq tentang: Aqidah, Syari'ah dan Tasawuf, Khitthah NU 1926, Hubungan Agama dan Pancasila, Negara Kesatuan RI Bentuk Final, Watak Sosial Ahlussunnah, Seni dan Agama. Jakarta: Duta Aksara Mulia.

Bizawie, Zainul Milal. 2014. Laskar ulama-santri \& resolusi jihad: garda depan menegakkan Indonesia, 1945-1949. Jakarta: Pustaka Compass.

Bruinessen, Martin van. 1994. NU Tradisi Relasi-Relasi Kuasa Pencarian Wacana Baru. Yogyakarta: LKiS.

Feillard, Andree. 2008. NU Vis-A-Vis negara pencarian isi bentuk dan makna. ed. Lesmana. Yogyakarta: LKiS.

Goncing, Nurlira. 2015. “Politik Nahdatul Ulama dan Orde Baru." The Politics: Jurnal Magister Ilmu Politik Universitas Hasanuddin 1(1): 61-74. http://journal.unhas.ac.id/index.php/politics/article/ view/134.

Hakim, Lukman. 2004. Perlawanan Islam kultural: relasi asosiatif pertumbuhan civil society dan doktrin Aswaja NU. Jakarta: Pustaka Eureka.

Hatta, Mohammad. 1969. Sekitar Proklamasi 17 Agustus 1945. Jakarta: Tintamas Press.

Ibn Hisyam, Abu Muhammad Abdul Malik. 1994. As-Sirah an-Nabawiyah li Ibni Hisyam. ed. Sa'id Muhammad. Beirut: Dar al-Fikr.

Kasid, Aminudin. 2015. Pengantar Ilmu Sejarah. Semarang: Unnes Press.

Kusuma, A. B. 2004. Lahirnya Undang-Undang Dasar 1945. Jakarta: Badan Penerbit Fakultas Hukum Universitas Indonesia.

Marijan, Kacung. 1992. Quo Vadis NU Setelah Kembali ke Khittah 1926. Jakarta: Erlangga.

Masdar, Umaruddin. 1999. Membaca Pikiran Gus Dur dan Amien Rais tentang Demokrasi. Yogyakarta: Pustaka Pelajar.

Mazrui, Ali A., Shalahudin Kafrawi, Alamin M. Mazrui, dan Ruzima Sebuharara, ed. 2006. Islam between Globalization \& Counter-terrorism. Oxford: Currey.

Miri, M. Djamaludin, dan Imam Ghazali Said, ed. 2005. Ahkamul Fuqaha - Solusi Problematika Aktual Hukum Islam: Keputusan Muktamar, Munas, dan Konbes Nahdlatul Ulama (1926-2004 M). Surabaya: LTN NU Jawa Timur \& Diantama.

Moesa, Ali Maschan. 2007. Nasionalisme Kiai: Konstruksi Sosial Berbasis Agama. Yogyakarta: LKiS.

Mukhdlor, Zuhdi A. 1996. NU dan Politik. Yogjakarta: PT. Gunung Jati dan Pondok Pesantren alMunawwir Krapyak.

Muzadi, Abdul Muchith. 2007. NU dalam Perspektif Sejarah dan Ajaran: Refleksi 65 Tahun Ikut NU. Surabaya: Khalista. 
Neuman, W. Laurence. 1994. Sosial Research Methode Qualitative and Quantitative Approaches. Needham Massachusetts: Allyn and Bacon.

Noer, Deliar. 1994. Gerakan Moderen Islam di Indonesia. Jakarta: LP3ES.

Notosusanto, Nugroho. 1978. Teori Sejarah dan Perannya dalam rangka Studi Sejarah. Jakarta: UI Press.

PBNU. 1979. Program Dasar Pengembangan Lima Tahun Nahdlatul Ulama: Keputusan Muktamar NU XXVI. Jakarta: Lajnah Ta'lif wa al-Nasyr PBNU.

_—_. 1983. Pokok-pokok Pikiran tentang Pemulihan Khittah NU 1926. Jakarta: Lajnah Ta'lif wa alNasyr PBNU.

Ramage, Douglas E. 2002. Percaturan Politik di Indonesia: Demokrasi, Islam, dan Ideologi Toleransi. ed. Hartono Hadikusumo. Yogyakarta: Mata Bangsa.

Setiawan, Zudi. 2010. "Pemikiran dan Kebijakan Nahdlatul Ulama dalam Menjaga Kedaulatan Wilayah Negara Kesatuan Republik Indonesia pada Era Reformasi (1998-2009)." Spektrum: Jurnal ilmu politik hubungan internasional 7(1): 72-86.

Siddiq, KH. Achmad. 1985. Islam, Pancasila dan Ukhuwah Islamiyyah. Jakarta: Lajnah wa al-Nars PBNU dan Penerbit Sumber Barokah.

Surakhmad, Winarno. 1982. Pengantar Penelitian Ilmiah, Dasar Metode dan Tehnik. Bandung: Tarsito Press.

Suroso. 1987. Nahdlatul Ulama, Eksistensi Peran dan Prospeknya. Malang: LP Ma'arif Malang.

Taimiyyah, Ibn. 1988. Al-Siyāsah al-Shar'iyyah fi Ișlāhi al-Ra'ïy wa al-Ra'ìyyah. Beirut: Dār al-Kutub alIlmiyyah.

Wahid, Abdurrahman. 1991. "Kemerdekaan: Suatu Refleksi." Aula.

——_. 1999. Mengurai Hubungan Agama dan Negara. Jakarta: RajaGrafindo. . 2001. Pergulatan Negara, Agama, dan Kebudayaan. Depok: Desantara.

Wasid. 2010. Gus Dur Sang Guru Bangsa: Pergolakan Islam, Kemanusiaan dan Kebangsaan. Yogyakarta: Interpena. 
JPW (Jurnal Politik Walisongo) - Vol. 1, No. 1 (2019) 